\title{
Investigation of Fungi Causing Twig Blight Diseases on Peach Trees in South Carolina
}

\author{
Martha H. Froelich and Guido Schnabel ${ }^{\dagger}$ \\ Department of Plant and Environmental Sciences, Clemson University, Clemson, SC 29634
}

\begin{abstract}
A survey of fungal pathogens causing twig blight on commercial peach trees was conducted in South Carolina in the fall of 2016. Shoots with cankers, pycnidia, and dieback were collected from six locations around the state. Isolates obtained from these samples were identified as Botryosphaeria obtusa, Phomopsis amygdali, Leucostoma persoonii, and Cytospora sp., based on colony morphology, conidia size and shape, and ribosomal DNA sequence analysis. L. persoonii was the most prevalent species and was isolated in five of the six locations, followed by $P$. amygdali and B. obtusa. The sensitivity of representative isolates of B. obtusa, $P$. amygdali, and $L$. persoonii to fungicides of different FRAC codes was evaluated. All species tested were sensitive to thiophanate-methyl (FRAC 1) and pyraclostrobin and azoxystrobin (both FRAC 11), whereas all species were resistant to boscalid and fluopyram (both FRAC 7). P. amygdali and B. obtusa were sensitive to difenoconazole and propiconazole (both FRAC 3),

whereas $L$. persoonii was moderately resistant. L. persoonii was the most virulent species based on expansion of mycelium in the cambium layer of 2-year-old, detached twig pieces. Bacterial spot (BS)-sensitive cultivar 'O'Henry' was most susceptible to B. obtusa compared with BS-sensitive 'Summerprince', brown rot (BR)-resistant 'Contender', and BR-sensitive 'Coronet' but was least susceptible to L. persoonii. Coronet was most susceptible to $L$. persoonii. There were no significant differences between susceptibility of the cultivars to $P$. amygdali. This study established that $L$. persoonii is currently the most frequent twig blight pathogen in South Carolina, perhaps owing to its superior fitness. Some fungicides were effective in controlling all twig blight pathogens and may therefore be useful for chemical management strategies. Our study also provides the first evidence that the genetic basis of resistance to BS and BR in peach trees is not necessarily linked to tolerance to wood pathogens.
\end{abstract}

Twig dieback reduces fruiting wood and therefore can impact yield potential in commercial peach (Prunus persica [L.] Batsch) orchards. Abiotic factors such as shading by a dense canopy, drought, or nutrient imbalances can cause shoots to die back (Johnson 2008; Proebsting and Middleton 1980). There are also several biotic causes of twig blight, including that caused by Pseudomonas syringae van Hall (Cameron 1962). However, most often, biotic twig blight is attributed to fungal pathogens. These pathogens require an opening in the wooden tissue through which to enter (Cohoon and Daines 1956; Luepschen et al. 1979; Pusey 1989; Tekauz and Patrick 1974). Because the pathogens are often opportunistic on weakened hosts, they may infect trees that have already been infected with another twig blight pathogen (Hildebrand 1947). Other research also indicates that multiple infections of twig blight canker pathogens can occur at the same time (Bai et al. 2015). Other factors such as insect damage, drought, and freeze damage also increase the probability of a twig blight fungal infection (Bertrand et al. 1976; Dhanvantari 1978; Willison 1933). There has also been research to suggest that excess nitrogen increases susceptibility to twig blight (Simoes et al. 2010).

No systematic survey of twig blight-causing pathogens has been conducted in the southeast, but Phomopsis amygdali (Delacr.) J.J. Tuset \& M.T. Portilla, Botryosphaeria dothidea (Moug. Ex Fr.) Ces. \& De Not., Botryosphaeria obtusa (Schwein.) Shoemaker, and Leucostoma persoonii (Nitschke) Höhn have been reported to cause peach twig dieback elsewhere (Adams et al. 2002; Britton and Hendrix 1982; Farr et al. 1999; Hammar 1989). P. amygdali and $L$. persoonii have been reported to infect through leaf, bud scale, stipule, fruit scars, and blossoms (Cohoon and Daines 1956; Gairola

${ }^{\dagger}$ Corresponding author: Guido Schnabel; E-mail: schnabe@clemson.edu

Funding: This material is based on work supported by NIFA/USDA, under project number 1700501 and by the South Carolina Department of Agriculture Specialty Crop Block Grant program.

Accepted for publication 28 September 2018.

(c) 2019 The American Phytopathological Society and Powell 1970; Hildebrand 1947; Tekauz and Patrick 1974). Botryosphaeria spp. have been reported to enter into wooden tissue through lenticels (Weaver 1974). Most twig blight fungi may also infect trees through wounds from pruning or other mechanical damage (Cohoon and Daines 1956; Luepschen et al. 1979; Pusey 1989). After infection, cankers are formed, which mature and kill the entire infected shoot (Lalancette and Robison 2001). Pycnidia then form, which produce cirri bearing conidia under rainy or humid conditions (Bertrand 1976; Haenseler and Daines 1941; Lalancette and Robison 2001; Weaver 1974). The conidia are dispersed by water and can spread disease throughout an orchard (Amponsah et al. 2009; Lalancette and Robison 2001; Luepschen and Rohrbach 1969). Symptoms of these diseases include cankers or lesions, gumming of wounded areas, darkening and necrosis of wooden tissue, twig or scaffold limb dieback, and, most severely, death of the tree (Alfieri et al. 1974; Haenseler and Daines 1941; Uddin and Stevenson 1998; Weaver 1974).

The sensitivity of many wood pathogens to recently registered fungicides is unknown, and so is the susceptibility to dieback disease of newer cultivars with known resistance traits to other peach diseases. The objectives of this study were to (i) identify to the species level the fungi causing twig blight on peach trees in South Carolina, (ii) determine their sensitivity to commonly applied fungicides, and (iii) assess susceptibility of peach cultivars with variable tolerance to bacterial spot and brown rot to twig blight fungi.

\section{Materials and Methods}

Sample collection and pathogen isolation. One-year-old peach twigs displaying pycnidia were collected from six locations in South Carolina (Chesnee, Greer, McBee, Mountain Rest, and York) during 2016 (Table 1). To isolate the fungi, necrotic tissue underneath the periderm was removed and surface sterilized in $10 \%$ sodium hypochlorite for $1 \mathrm{~min}$ and rinsed in sterilized water for $1 \mathrm{~min}$. The tissue was then placed onto potato dextrose agar (PDA; $35.1 \mathrm{~g}$ of Difco PDA, $900 \mathrm{ml}$ of $\mathrm{H}_{2} \mathrm{O}$ ) and incubated in the dark at $22^{\circ} \mathrm{C}$ until fungal mycelia developed. Single-hyphal isolates were made of these cultures and stored on filter paper as described previously. 
DNA extraction, polymerase chain reaction (PCR) amplification, and sequencing of the internal transcribed spacer (ITS) regions 1 and 2. Fungal DNA was extracted according to a previous protocol (Chi et al. 2009), except that mycelia were grown over cellophane strips on PDA to ease mycelia removal. ITS region 1, ribosomal 5.8S subunit, and ITS 2 were amplified through PCR using the primers ITS1-F and ITS4. The PCR program consisted of $5 \mathrm{~min}$ at $94^{\circ} \mathrm{C} ; 35$ cycles of $40 \mathrm{~s}$ at $94^{\circ} \mathrm{C}, 1 \mathrm{~min}$ at $55^{\circ} \mathrm{C}$, and $2 \mathrm{~min}$ at $72^{\circ} \mathrm{C}$; and $10 \mathrm{~min}$ at $72^{\circ} \mathrm{C}$ in a Bio-Rad T100 Thermal Cycler. PCR products were subsequently sent to the Arizona State University DNA Laboratory for Sanger sequencing. The returned sequences underwent a search of the National Center for Biotechnology Information (NCBI) using the Basic Local Alignment Search Tool (BLASTn) to determine species identities. Sequencing editing, assembly, alignment, and phylogenetic tree creation were conducted using Geneious (version 11.0.4, Biomatters).

Fungicide sensitivity assay. To determine fungicide sensitivity, the half maximal effective concentration $\left(\mathrm{EC}_{50}\right)$ was determined using representative fungicides from four Fungicide Resistance Action Committee (FRAC) mode-of-action codes. Fungicides were selected based on grower use in peach orchards. The fungicides used included thiophanate-methyl (methyl benzimidazole carbamates, FRAC 1); propiconazole and difenoconazole (demethylation inhibitors, FRAC 3); boscalid and fluopyram (succinate dehydrogenase inhibitors [SDHI], FRAC 7); and pyraclostrobin and azoxystrobin (quinone outside inhibitors, FRAC 11). Malt extract agar (10 g of malt, $15 \mathrm{~g}$ of agar, 1 liter of $\mathrm{H}_{2} \mathrm{O}$ ) was amended with the abovementioned fungicides of FRAC 1, 3, and 11. Minimal medium (10 $\mathrm{g}$ of glucose, $1.5 \mathrm{~g}$ of $\mathrm{K}_{2} \mathrm{HPO}_{4}, 2 \mathrm{~g}$ of $\mathrm{KH}_{2} \mathrm{PO}_{4}, 1 \mathrm{~g}$ of $\left(\mathrm{NH}_{4}\right)_{2} \mathrm{SO}_{4}, 0.5 \mathrm{~g}$ of $\mathrm{MgSO}_{4} \cdot 7 \mathrm{H}_{2} \mathrm{O}, 2 \mathrm{~g}$ of yeast extract, $12.5 \mathrm{~g}$ of agar, 1 liter of $\mathrm{H}_{2} \mathrm{O}$ ) was used for FRAC 7 (Hu et al. 2011). Medium for FRAC 11 was additionally amended with salicylhydroxamic acid to block the alternative oxidase pathway. A preliminary study investigated the sensitivity of all isolates to $0.1,1$, and $10 \mu \mathrm{g} / \mathrm{ml}$ of active ingredient (a.i.). Three 4-mm-diameter mycelial plugs were taken from the periphery of 1- to 2-week-old cultures and placed on each fungicide-amended and unamended control Petri dish and incubated in the dark at $22^{\circ} \mathrm{C}$. Their average diameters were recorded when the three colonies were nearly touching. Upon evaluation of these, a second assay was conducted using refined concentrations. The concentrations $0.1,0.3$, and $1.0 \mu \mathrm{g} / \mathrm{ml}$ of a.i. were used for testing thiophanate-methyl (FRAC 1) for all pathogens except $B$. obtusa. For B. obtusa, 0.03, 0.1, 0.3, 1.0, and $3.0 \mu \mathrm{g} / \mathrm{ml}$ of a.i. was used. Boscalid and fluopyram (FRAC 7) were tested at $3,10,30$, and $100 \mu \mathrm{g} / \mathrm{ml}$ of a.i. and pyraclostrobin and azoxystrobin (FRAC 11) at 0.01, 0.03, 0.1, 0.3, 1.0, and $3.0 \mu \mathrm{g} / \mathrm{ml}$ of a.i. Data from the preliminary study of propiconazole and difenoconazole (FRAC 3) were sufficient to calculate $\mathrm{EC}_{50}$, so no further testing was conducted. The aforementioned procedure was repeated on these new concentrations. These data were used to determine the fungicide concentrations at which $50 \%$ of fungal growth was inhibited.

Cultivar susceptibility assay. Four peach $(P$. persica) cultivars were selected based on their tolerances to two common peach diseases, brown rot (Monilinia fructicola) and bacterial spot (Xanthomonas arboricola pv. pruni). The cultivars chosen were 'Contender' (tolerant to brown rot [Pacheco et al. 2014]), 'Coronet' (susceptible to brown rot), 'Summerprince' (resistant to bacterial spot), and 'O'Henry' (susceptible to bacterial spot). Three trees were selected per cultivar, and 2-year-old wood was collected to produce three experimental replicates per tree. Peach wood was obtained from the Clemson University Musser Fruit Research Center in Seneca, South Carolina. One representative isolate each of B. obtusa, P. amygdali, and $L$. persoonii was chosen for inoculations based on $\mathrm{EC}_{50}$ data; the isolates with highest $\mathrm{EC}_{50}$ for each pathogen were selected.

Isolates were grown on PDA from permanent culture for 8 days in the dark at $22^{\circ} \mathrm{C}$. The collected wood was cut into approximately $12-$ $\mathrm{cm}$ sections. Wood section ends were sealed with Kilz 2 Latex primer to avoid desiccation. Twigs were sterilized for $5 \mathrm{~min}$ in $10 \%$ sodium hypochlorite solution, washed in sterilized distilled water for $1 \mathrm{~min}$, and allowed to dry in a laminar flow hood. A 4-mm-diameter core borer was used to remove discs from wood periderm. Plugs of mycelia were placed over the wounded areas and sealed with Parafilm. Two inoculations of the same pathogen were made per wood section, and measurements were averaged. Controls were prepared using plugs of sterile PDA. The wood was then placed inside one opaque plastic storage container in two layers separated by aluminum foil and allowed to incubate at room temperature for 7 days. The average necrotic area was estimated by multiplying length by width, and the entire experiment was repeated.

Statistical analysis. We used JMP (SAS Institute, Cary, NC) for all statistical modeling. Multivariate statistics included multiple linear regression and correlation metrics to understand the data structure and interactions. A two-way ANOVA was used to determine the significance of pathogen, cultivar, and their interactions to disease lesion area. When the full model, pathogen, and the interaction of pathogen and cultivar effect were statistically significant $(\alpha=$ 0.05 ), we compared means of each cultivar by pathogen as well as combined cultivars for each pathogen using the Tukey honestly significant difference post hoc comparison.

\section{Results}

A total of 111 isolates were collected from six locations in 2016 and grouped based on culture morphology on PDA. Morphology 1 was characterized by white mycelia that turned gray-green with age and grew an average of $68 \mathrm{~mm}$ in 6 days; morphology 2 by dark gray-green mycelia that also formed aerial mycelia and grew, on average, the entire diameter of the Petri dish $(85 \mathrm{~mm})$ within 6 days; morphology 3 by light yellow-green mycelia with no aerial extensions that turned green-brown with age and grew an average of $83 \mathrm{~mm}$ in 6 days; and morphology 4 by light-green mycelia with no aerial extensions that turned dark green with age and grew an average of $58 \mathrm{~mm}$ in 6 days (Fig. 1). These distinct colonies were later identified based on spore morphology as well as ribosomal DNA sequence analysis as $P$. amygdali, B. obtusa, L. persoonii, and Cytospora sp. B. obtusa conidia measured 15 to $26.25 \times 6.25$ to $10 \mu \mathrm{m}$ and were ellipsoidal, nonseptate, and initially hyaline but turned brown after maturation. $P$. amygdali $\alpha$-conidia measured 3.75 to $7.5 \times 2.5$ to $5 \mu \mathrm{m}$ and were straight, hyaline, nonseptate, and fusiform in shape. No $\beta$-conidia were observed. Conidia of $L$. persoonii were 2.5 to $6.25 \times 1.25$ to $2.5 \mu \mathrm{m}$ and were hyaline, nonseptate, allantoid, and slightly curved. The identity of Cytospora sp. was based solely upon DNA sequencing information. All species were found in at least two different locations. The most commonly found species by location were L. persoonii (five locations) and B. obtusa (three locations). The most frequently isolated species were $L$. persoonii (57 isolates) and $P$. amygdali (37 isolates; Table 1).

Table 1. Number of fungal pathogens collected from symptomatic twigs in South Carolina peach orchards

\begin{tabular}{lccccrrr}
\hline & \multicolumn{3}{c}{ Location } & & \\
\cline { 2 - 6 } Pathogen & Chesnee & Greer & McBee & Mountain Rest & Ridge Spring & York & Total \\
\hline Phomopsis amygdali & 20 & 0 & 0 & 0 & 1 & 0 & 37 \\
Botryosphaeria obtusa & 0 & 2 & 2 & 0 & 0 & 6 \\
Cytospora sp. & 4 & 0 & 0 & 16 & 0 & 11 \\
Leucostoma persoonii & 6 & 9 & 12 & 17 & 17 & 14 \\
Total & 30 & 11 & 14 & 57 & 111 \\
\hline
\end{tabular}


Colonies of different morphologies differed in ribosomal DNA sequences. The ITS regions of representative isolates of each distinct cultural morphology from each location were sequenced and revealed four fungal species known to cause twig blight on stone fruits. Morphology 1 sequences were highest in sequence identity to $P$. amygdali (100\% identity to accession number NR_119753); morphology 2 sequences were highest in sequence identity to $B$. obtusa (99.9\% identity to accession number HQ629955); morphology 3 sequences were highest in sequence identity to L. persoonii (99.8\% identity to accession number AF191180); and morphology 4 sequences were highest in sequence identity to Cytospora donetzica (98.4\% identity to accession number KY417729). The latter sequences varied by 8 nucleotides in the ITS1 and 2 regions, and thus we refer to these isolates as Cytospora sp. Because of this species uncertainty, the Cytospora sp. isolates were excluded from further experimentation.

Representatives of species exhibited differences in sensitivity to fungicides. The $\mathrm{EC}_{50}$ values for thiophanate-methyl (FRAC 1) ranged from 0.13 to $0.156,0.002$ to 0.064 , and 0.128 to $0.175 \mu \mathrm{g} / \mathrm{ml}$ for P. amygdali, B. obtusa, and L. persoonii, respectively (Table 2).
For difenoconazole, the $\mathrm{EC}_{50}$ values ranged from 0.049 to 0.289 , 0.026 to 0.207 , and 0.812 to $1.037 \mu \mathrm{g} / \mathrm{ml}$ for $P$. amygdali, B. obtusa, and $L$. persoonii, respectively. For propiconazole, the values ranged from 1.031 to $1.189,0.094$ to 0.585 , and 0.929 to $2.284 \mu \mathrm{g} / \mathrm{ml}$ for $P$. amygdali, B. obtusa, and L. persoonii, respectively (Table 2), indicating that $L$. persoonii exhibited moderate resistance to both FRAC 3 fungicides. Overall, difenoconazole had higher intrinsic activity compared with propiconazole. All pathogens were resistant to FRAC 7 fungicides based on $\mathrm{EC}_{50}$ values for boscalid and fluopyram equal or greater than $56.819 \mu \mathrm{g} / \mathrm{ml}$. Most isolates were sensitive to FRAC 11 pyraclostrobin and azoxystrobin with $\mathrm{EC}_{50}$ values less than $0.01 \mu \mathrm{g} / \mathrm{ml}$. Azoxystrobin had higher intrinsic activity compared with pyraclostrobin. The highest $\mathrm{EC}_{50}$ of $0.611 \mu \mathrm{g} / \mathrm{ml}$ was identified for a $B$. obtusa isolate. These data show that all species were sensitive to FRAC 1 and FRAC 11 fungicides, that sensitivity to FRAC 3 fungicides was species dependent, and that FRAC 7 fungicides were ineffective.

Infection symptoms of the twigs were similar for all pathogens. Bark tissue appeared slightly sunken, and brown, necrotic lesions
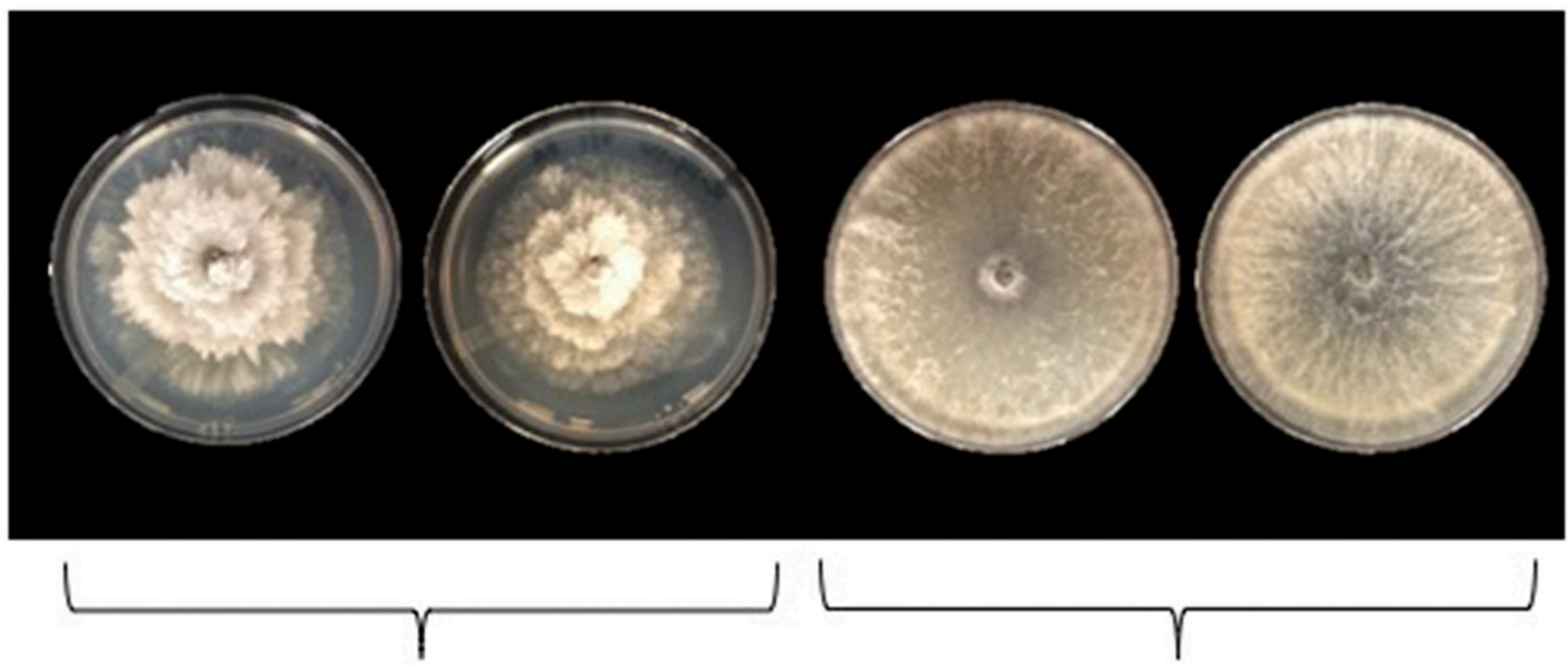

Phomopsis amygdali

Botryosphaeria obtusa
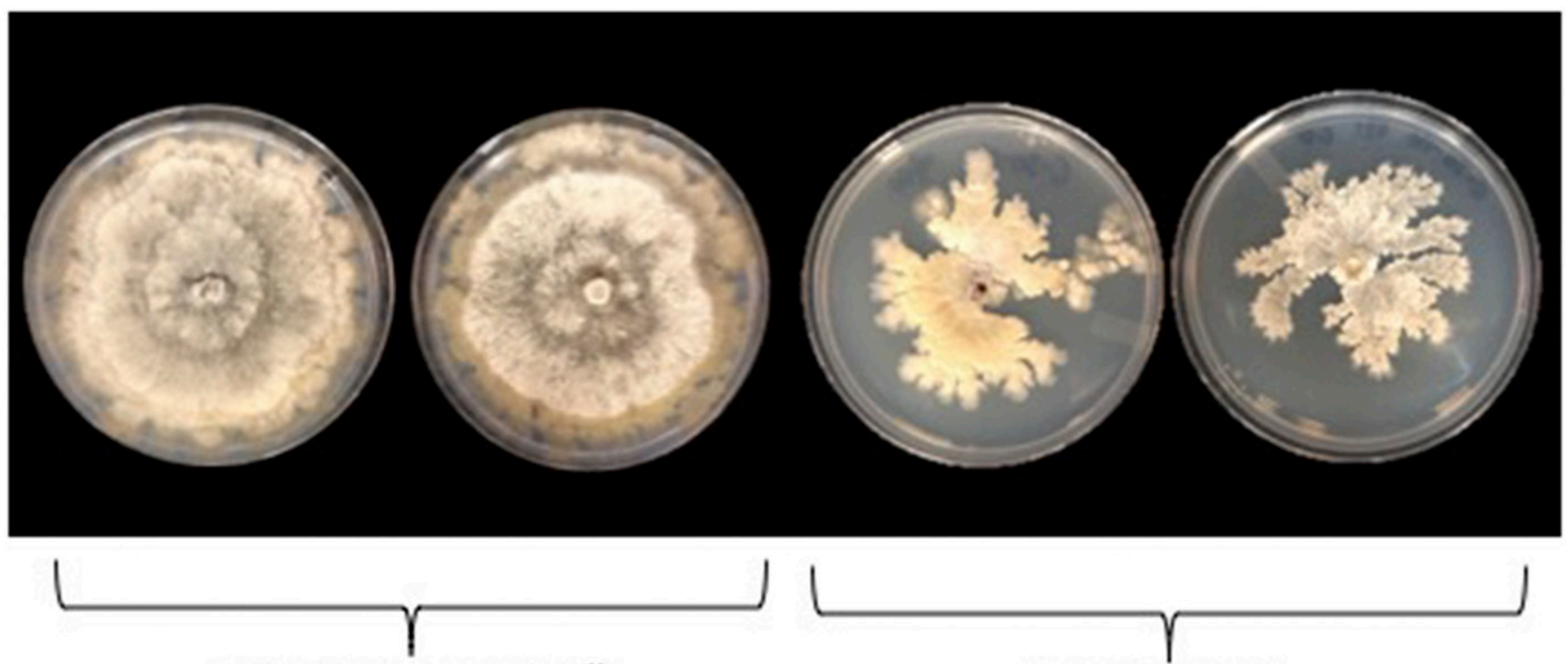

Leucostoma persoonii

Cytospora sp.

Fig. 1. Representative morphologies of 2016 South Carolina twig blight isolates grown on potato dextrose agar in the dark for 7 days at $22^{\circ} \mathrm{C}$. 
formed underneath the bark. Gumming occurred out of wounds of many twigs. Although infection symptoms were alike, we identified differences in virulence and cultivar response between the three pathogens investigated (Fig. 2). L. persoonii was most virulent and had the largest mean lesion area; on average, it grew 3.9-fold faster than B. obtusa and 3.0-fold faster P. amygdali. There was no difference in disease susceptibility between cultivars for $P$. amygdali. However, there were significant differences between cultivars for both $B$. obtusa and $L$. persoonii. Based on the premise that lesion area is correlated with host resistance, O'Henry appeared more susceptible to B. obtusa compared with the other cultivars, but there were no significant susceptibility differences between the other cultivars. O'Henry was least susceptible to $L$. persoonii when compared with the other cultivars. Coronet was most susceptible to $L$. persoonii followed by Contender.

\section{Discussion}

Our survey determined that there are multiple fungal pathogens causing twig blight in the state of South Carolina. To our knowledge, this is the first survey of its kind conducted in the main peach production regions in South Carolina, although the pathogens were either known or suspected to exist in the region. Peach canker or constriction canker causing twig blight was first described as a disease caused by Fusicoccum amygdali in 1941 (Haenseler and Daines 1941). Later, F. amygdali was reclassified as $P$. amygdali and was recognized as the species causing canker on peach in the southeastern United States, including South Carolina (Farr et al.1999). Initially, gummosis of peach was observed in Georgia, and the causal agent was described as B. dothidea (Moug. Ex Fr.) Ces. \& De Not. (Weaver 1974). Later, B. obtusa was described in Georgia as another causal agent of the disease (Britton and Hendrix 1982). Generally, Leucostoma canker is considered a disease that occurs in cooler, more northern climates. However, multiple studies have included L. persoonii isolates collected from North Carolina and Florida (Adams et al. 2002; Alfieri et al. 1974; Hammar 1989), indicating that the pathogen is present in the southeastern United States. Available research indicates $P$. amygdali and $B$. obtusa/B. dothidea have been the most prevalent twig blight pathogens in the southeastern United States. In fact, in the 2018 Southeastern Peach, Nectarine, and Plum Pest Management and Culture Guide, L. persoonii is not even mentioned as an issue for peach producers, much less are there control options provided (Blaauw et al. 2018). Interestingly, our survey determined that $L$. persoonii was the most prevalent twig blight pathogen. This not only is a first formal report of this pathogen on peach in South Carolina but also indicates that a shift may have taken place in which $L$. persoonii appears now to be the most prevalent agent causing twig dieback. The superior virulence observed in our twig study suggests that $L$. persoonii has outcompeted other pathogens in the area. To our knowledge, there are no other published studies comparing the virulence of $L$. persoonii to other pathogens. Leucostoma canker and bacterial canker, caused by $P$. syringae, have frequently been found together in peach (Alfieri et al. 1974). However, scaffold limb dieback in South Carolina has typically been attributed to bacterial canker; research has suggested that Cytospora canker is a secondary disease to bacterial canker (Ritchie and Clayton 1981). Because of these findings indicating the prevalence of $L$. persoonii, it would be worth revisiting the subject of bacterial canker being the main causal agent of scaffold limb dieback.

Several fungicidal active ingredients were tested to determine sensitivity of the pathogens in vitro. We found insensitivity to FRAC 7 fungicides in all of the pathogens. Recent research on $B$. dothidea also suggests the SDHI fungicides are ineffective in controlling mycelial growth in vitro (Dai et al. 2017). Because all pathogens were equally insensitive to the FRAC 7 fungicides, we suspect a natural, inherent insensitivity of these twig blight pathogens to this mode of action. We do not suspect tolerance through fungicide selection. Other results indicate that some FRAC codes may be useful to protect trees from infection from all wood pathogens identified in this study, perhaps after hail, pruning, or during leaf drop when injuries to the tree increase infection risk. A previous study found that carbendazim (FRAC 1), prochloraz (FRAC 3), and difenoconazole (FRAC 3) were effective in preventing infection of $P$. amygdali in the field (Ji et al. 2013). Similarly, our results indicate that difenoconazole was effective in controlling $P$. amygdali in vitro. Another study indicated that captan (FRAC M04), chlorothalonil (FRAC M05), and azoxystrobin (FRAC 11) were most effective in reducing canker incidence and severity in the field but that no fungicide was able to achieve more than $75 \%$ control of $P$. amygdali (Lalancette and Robison 2002). Our assay did not include multisite fungicides such as captan or chlorothalonil but did achieve excellent control with FRAC 11 fungicides azoxystrobin and pyraclostrobin. Little is known about the efficacy of modern fungicides for $L$. persoonii control. Previous research conducted on $L$. persoonii has shown that benomyl (FRAC 1) and captafol (FRAC M04) reduced disease incidence when applied in fall and the beginning of spring (Northover 1992). Another study on another Leucostoma canker pathogen, L. cincta, conflicted with this and concluded that captafol was ineffective (Grosclaude 1985). However, now, many peach pathogens are resistant to

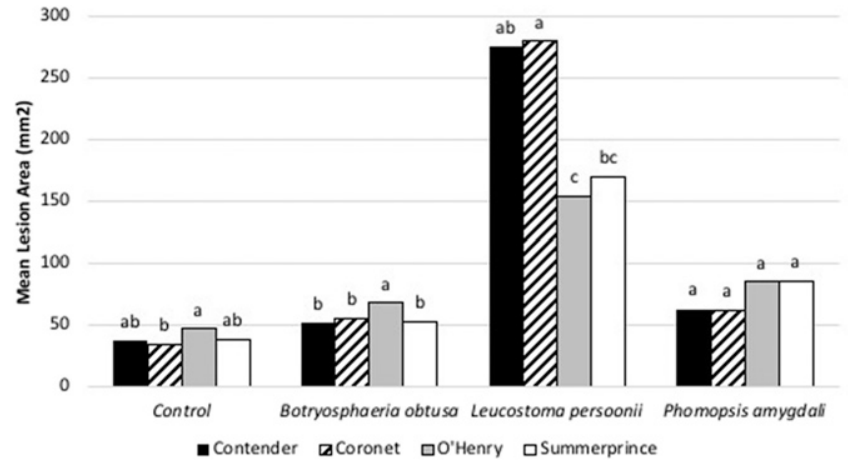

Fig. 2. Mean lesion area caused by three pathogens in wood segments of four cultivars after 7 days of incubation at $22^{\circ} \mathrm{C}$.

Table 2. Sensitivity of pathogens to fungicides from four Fungicide Resistance Action Committee (FRAC) mode-of-action codes

\begin{tabular}{|c|c|c|c|c|c|c|c|c|}
\hline \multirow[b]{2}{*}{ Pathogen } & \multirow[b]{2}{*}{ Isolate } & \multicolumn{7}{|c|}{$\mathrm{EC}_{50}$ values $(\mu \mathrm{g} / \mathrm{ml})^{\mathbf{a}}$} \\
\hline & & $\begin{array}{c}\text { Thiophanate- } \\
\text { methyl (FRAC 1) }\end{array}$ & $\begin{array}{l}\text { Difenoconazole } \\
\text { (FRAC 3) }\end{array}$ & $\begin{array}{l}\text { Propiconazole } \\
\text { (FRAC 3) }\end{array}$ & $\begin{array}{c}\text { Boscalid } \\
\text { (FRAC 7) }\end{array}$ & $\begin{array}{c}\text { Fluopyram } \\
\text { (FRAC 7) }\end{array}$ & $\begin{array}{c}\text { Pyraclostrobin } \\
\text { (FRAC 11) }\end{array}$ & $\begin{array}{c}\text { Azoxystrobin } \\
\text { (FRAC 11) }\end{array}$ \\
\hline \multirow{3}{*}{$\begin{array}{r}\text { Phomopsis } \\
\text { amygdali }\end{array}$} & $C-1-16$ & 0.13 & 0.289 & 1.189 & $>100$ & $>100$ & $<0.01$ & $<0.01$ \\
\hline & RS-5-16 & 0.156 & 0.093 & 1.182 & $>100$ & $>100$ & $<0.01$ & $<0.01$ \\
\hline & RS-10-16 & 0.13 & 0.049 & 1.031 & $>100$ & $>100$ & $<0.01$ & $<0.01$ \\
\hline \multirow{3}{*}{$\begin{array}{l}\text { Botryosphaeria } \\
\text { obtusa }\end{array}$} & MB-5-16 & 0.064 & 0.026 & 0.42 & $>100$ & $>100$ & $<0.01$ & $<0.01$ \\
\hline & Y-6-16A & 0.003 & 0.053 & 0.094 & $>100$ & $>100$ & 0.611 & $<0.01$ \\
\hline & MR-14-16 & 0.002 & 0.207 & 0.585 & 56.819 & $>100$ & 0.01 & $<0.01$ \\
\hline \multirow{3}{*}{$\begin{array}{l}\text { Leucostoma } \\
\text { persoonii }\end{array}$} & Y-2-16 & 0.128 & 0.858 & 0.929 & $>100$ & $>100$ & 0.158 & $<0.01$ \\
\hline & MB-8-16 & 0.175 & 0.812 & 1.933 & $>100$ & $>100$ & 0.068 & $<0.01$ \\
\hline & Y-17-16B & 0.159 & 1.037 & 2.284 & $>100$ & $>100$ & 0.078 & 0.206 \\
\hline
\end{tabular}

${ }^{\mathrm{a}} \mathrm{EC}_{50}=$ half maximal effective concentration. 
benomyl (Bernstein et al. 1995; Penrose and Koffman 1977), and captafol is banned for use on peach. Captafol was also found to reduce incidence of fungal gummosis (Beckman et al. 2003). In that same study, the authors found that captan was less effective than captafol. In another study, they found that propiconazole was most effective and that azoxystrobin had low efficacy against $B$. obtusa (Ji et al. 2012). Our results agree that propiconazole achieved some control of B. obtusa, but the most control was achieved with azoxystrobin. Conflicting results between studies and the lack of research comparing fungicides that are currently used in peach production make it difficult to definitively suggest fungicides to use for preventative control of twig blight pathogens. However, our research and previous studies provide evidence for the effectiveness of FRAC 1 and FRAC 11 fungicides in providing control for some of these twig blight fungi. Additionally, the FRAC M4 fungicides may also provide control for these pathogens based on previous research. Because this fungicide efficacy study was an in vitro experiment using artificial media, it is difficult to judge how these fungicides will behave in a field setting. In the future, these fungicides should be applied in a field situation to determine the field efficacy of these compounds.

Our results indicate that certain cultivars possessed differing levels of susceptibility to the different pathogens. However, the susceptibility was not consistent for cultivars across all pathogens. Several researchers have noted that many plant tissues form a lignosuberized layer upon wounding and its importance for fungal infection (Biggs and Britton 1988; Biggs and Miles 1985, 1988; Biggs and Peterson 1990; Rittinger et al. 1987). Previous research on cultivar susceptibility to Leucostoma spp. observed the potential influence of suberin formation in wound sites and cultivar susceptibility; essentially, cultivars that produced suberin sooner after damage to the wood were generally more tolerant to Leucostoma spp. infection (Biggs and Miles 1985, 1988; Biggs and Peterson 1990). One may hypothesize that this trend may extend to multiple fungal twig blight pathogens. Interestingly, however, our results indicate that not all cultivars display the same tolerance to $L$. persoonii, $P$. amygdali, and B. obtusa (e.g., O'Henry was least tolerant to B. obtusa and most tolerant to $L$. persoonii). Therefore, tolerance of peach cultivars to twig blight pathogens may not be based on the swift formation of a lignosuberized layer in the wooden tissue.

We selected the cultivars in this study based upon their susceptibility and tolerance to brown rot and bacterial spot. Brown rot resistance is associated with three genomic regions (Pacheco et al. 2014). Similarly, bacterial spot resistance is believed to be controlled by multiple genes, but less is understood about the exact mechanism (Yang et al. 2013). Contender and Coronet (tolerant and susceptible to brown rot, respectively) were the two least tolerant cultivars to L. persoonii. They were two of the most tolerant cultivars to B. obtusa. There was no difference between all cultivars for $P$. amygdali. These differences suggest that the same genetic basis for disease tolerance to brown rot in these cultivars is not the same mechanism governing disease tolerance to twig blight pathogens. Summerprince and O'Henry (tolerant and susceptible to bacterial spot, respectively) were the most tolerant to L. persoonii. O'Henry was least tolerant and Summerprince was one of the most tolerant to B. obtusa. In this case, B. obtusa had a similar tolerance profile to that of bacterial spot. However, $L$. persoonii did not. These differences also suggest that disease tolerance to $L$. persoonii is independent from that of bacterial spot in these cultivars but may be related in B. obtusa. However, to allow for maximum comparison between both cultivars and pathogens, the lesion areas in this study were measured at the same time for all twigs. For this reason, we believe that if $P$. amygdali and $B$. obtusa were allowed to grow for a longer period of time, we may have seen greater differences between cultivar susceptibility within species. In the future, a follow-up study should be conducted that allows for longer growth of these pathogens to differentiate further between cultivars within pathogen.

Our results provide promising information about the scope of twig blight pathogens in South Carolina as well as how we can develop tailored management strategies. In the follow-up studies for field testing of fungicides, it would be beneficial to include multisite fungicides to provide more context to the chemical control of twig blight fungi. Similarly, although our detached branch inoculations provided promising information, field testing should be conducted using attached branches to determine susceptibility of cultivars in a real-world setting. In summary, our study indicates that twig blight of peach in South Carolina and perhaps in other southeastern states is caused by multiple pathogens but primarily by $L$. persoonii. This pathogen is capable of causing severe cankers on scaffold limbs, leading to premature peach tree decline, and thus developing management practices will be important.

\section{Acknowledgments}

Technical contribution number 6666 of the Clemson University Experiment Station. We thank Brodie Cox, Melissa Muñoz, and Karen Bryson for technical support and Simon Li for statistical help.

\section{Literature Cited}

Adams, G. C., Surve-Iyer, R. S., and Iezzoni, A. F. 2002. Ribosomal DNA sequence divergence and group I introns within the Leucostoma species $L$. cinctum, L. persoonii, and L. parapersoonii sp. nov., ascomycetes that cause Cytospora canker of fruit trees. Mycologia 94:947-967.

Alfieri, S. A. J., Seymour, C. P., and French, W. J. 1974. Cytospora canker of peach in Florida. Proc. Fla. State Hortic. Soc. 86:308-309.

Amponsah, N. T., Jones, E. E., Ridgway, H. J., and Jaspers, M. V. 2009. Rainwater dispersal of Botryosphaeria conidia from infected grapevines. N. Z. Plant Prot. 62:228-233.

Bai, Q., Zhai, L., Chen, X., Hong, N., Xu, W., and Wang, G. 2015. Biological and molecular characterization of five Phomopsis species associated with pear shoot canker in China. Plant Dis. 99:1704-1712.

Beckman, T. G., Pusey, P. L., and Bertrand, P. F. 2003. Impact of fungal gummosis on peach trees. HortScience 38:1141-1143.

Bernstein, B., Zehr, E. I., Dean, R. A., and Shabi, E. 1995. Characteristics of Colletotrichum from peach, apple, pecan, and other hosts. Plant Dis. 79: 478-482.

Bertrand, P. F. 1976. Release and dispersal of conidia and ascospores of Valsa leucostoma. Phytopathology 66:987-991.

Bertrand, P. F., English, K., Uriu, K., and Schick, F. J. 1976. Late season water deficits and the development of Cytospora canker in French prune. Phytopathology 66:1318-1320.

Biggs, A. R., and Britton, K. O. 1988. Presymptom histopathology of peach trees inoculated with Botryosphaeria obtusa and B. dothidea. Phytopathology 78: 1109-1118.

Biggs, A. R., and Miles, N. W. 1985. Suberin deposition as a measure of wound response in peach bark. HortScience 20:903-905.

Biggs, A. R., and Miles, N. W. 1988. Association of suberin formation in uninoculated wounds with susceptibility to Leucostoma cincta and L. persoonii in various peach cultivars. Phytopathology 78:1070-1074.

Biggs, A. R., and Peterson, C. A. 1990. Effect of chemical applications to peach bark wounds on accumulation of lignin and suberin and susceptibility to Leucostoma persoonii. Phytopathology 80:861-865.

Blaauw, B., Brannen, P., Bellinger, B., Lockwood, D., and Ritchie, D. 2018. 2018 Southeastern Peach, Nectarine, and Plum Pest Management and Culture Guide. University of Georgia Cooperative Extension, Athens, GA.

Britton, K. O., and Hendrix, F. F. 1982. Three species of Botryosphaeria cause peach tree gummosis in Georgia. Plant Dis. 66:1120-1121.

Cameron, H. R. 1962. Diseases of Deciduous Fruit Trees Incited by Pseudomonas syringae van Hall. Agricultural Experimental Station, Oregon State University, Corvallis.

Chi, M.-H., Park, S.-Y., and Lee, Y.-H. 2009. A quick and safe method for fungal DNA extraction. Plant Pathol. J. 25:108-111.

Cohoon, D. F., and Daines, R. H. 1956. Peach canker (Fusicoccum amygdali): Times and sites of infections. Plant Dis. Rep. 40:304-308.

Dai, D. J., Wang, H. D., Wang, Y. P., and Zhang, C. Q. 2017. Management of Chinese hickory (Carya cathayensis) trunk canker through effective fungicide application programs and baseline sensitivity of Botryosphaeria dothidea to trifloxystrobin. Australas. Plant Pathol. 46:75-82.

Dhanvantari, B. N. 1978. Cold predisposition of dormant peach twigs to nodal cankers caused by Leucostoma spp. Phytopathology 68:1779-1783.

Farr, D. F., Castlebury, L. A., and Pardo-Schultheiss, R. A. 1999. Phomopsis amygdali causes peach shoot blight of cultivated peach trees in the southeastern United States. Mycologia 91:1008-1015.

Gairola, C., and Powell, D. 1970. Cytospora peach canker in Illinois. Plant Dis Rep. 54:832-835.

Grosclaude, C. 1985. Fungicide or antagonistic action of some pesticides towards Cytospora cincta on peach tree. Phytoma Fr. 372:37-38.

Haenseler, C. M., and Daines, R. H. 1941. Peach canker caused by Fusicoccum amygdali. (Abstr.) Phytopathology 31:10.

Hammar, S. 1989. Association of double-stranded RNA with low virulence in an isolate of Leucostoma persoonii. Phytopathology 79:568-572.

Hildebrand, E. M. 1947. Perennial peach canker and the canker complex in New York with methods of control. Agric. Exp. Stn. Mem. 276. Cornell University, Ithaca, NY. 
Hu, M.-J., Luo, C.-X., Grabke, A., and Schnabel, G. 2011. Selection of a suitable medium to determine sensitivity of Monilinia fructicola mycelium to SDHI fungicides. J. Phytopathol. 159:616-620.

Ji, Z., Tong, Y., Chen, X., and Xu, J. 2012. Toxicity of fungicides to peach fungal gummosis pathogens under laboratory conditions. South China Fruits. 41: $39-41,46$

Ji, Z. L., Dai, H. J., Jin, J. F., and Xiong, C. Z. 2013. Virulence and control efficacy in field of fungicides on Phomopsis amygdali of peach. J. Fruit Sci. 30:281-284.

Johnson, R. S. 2008. Nutrient and water requirements of peach trees. Pages 303-331 in: Peach: Botany, Production, and Uses. D. R. Layne and D. Bassi, eds. CABI, Wallingford, UK.

Lalancette, N., and Robison, D. M. 2001. Seasonal availability of inoculum for constriction canker of peach in New Jersey. Phytopathology 91:1109-1115.

Lalancette, N., and Robison, D. M. 2002. Effect of fungicides, application timing, and canker removal on incidence and severity of constriction canker of peach. Plant Dis. 86:721-728.

Layne, D. R., and Bassi, D. 2008. The Peach: Botany, Production and Uses. CABI, Wallingford, U.K.

Luepschen, N. S., Hetherington, J. E., Stahl, F. J., and Mowrer, K. E. 1979. Cytospora canker of peach trees in Colorado: Survey of incidence, canker location and apparent infection courts. Plant Dis. Rep. 63:685-687.

Luepschen, N. S., and Rohrbach, K. G. 1969. Cytospora canker of peach trees: Spore availability and wound susceptibility. Plant Dis. Rep. 53:869-872.

Northover, J. 1992. Effect of fungicides on incidence of Leucostoma canker of peach and fungal microflora of pruning wounds. Can. J. Plant Pathol. 14: 22-29.

Pacheco, I., Bassi, D., Eduardo, I., Ciacciulli, A., Pirona, R., Rossini, L., and Vecchietti, A. 2014. QTL mapping for brown rot (Monilinia fructigena) resistance in an intraspecific peach (Prunus persica L. Batsch) F1 progeny. Tree Genet. Genomes 10:1223-1242.

Penrose, L. J., and Koffman, W. 1977. Tolerance of Sclerotinia fructicola to benzimidazole fungicides and control of the fungus. Phytopathology 88:153-164

Proebsting, E. L., and Middleton, J. E. 1980. The behavior of peach and pear trees under extreme drought stress. Am. Soc. Hortic. Sci. J. 105:380-385.

Pusey, P. L. 1989. Availability and dispersal of ascospores and conidia of Botryosphaeria in peach orchards. Phytopathology 79:635-639.

Ritchie, D. F., and Clayton, C. N. 1981. Peach tree short life: A complex of interacting factors. Plant Dis. 65:462-469.

Rittinger, P. A., Biggs, A. R., and Peirson, D. R. 1987. Histochemistry of lignin and suberin deposition in boundary layers formed after wounding in various plant species and organs. Can. J. Bot. 65:1886-1892.

Simoes, M. P., Luz, J. P., St Aubyn, A., Mexia, A., and Calouro, M. F. 2010. Effect of nitrogen levels and climate factors on susceptibility of peach trees to Phomopsis amygdali. Acta Hortic. 868:451-456.

Tekauz, A., and Patrick, Z. A. 1974. The role of twig infections on the incidence of perennial canker of peach. Phytopathology 64:683-688.

Uddin, W., and Stevenson, K. L. 1998. Seasonal development of Phomopsis shoot blight of peach and effects of selective pruning and shoot debris management on disease incidence. Plant Dis. 82:565-568.

Weaver, D. J. 1974. A gummosis disease of peach trees caused by Botryosphaeria dothidea. Phytopathology 64:1429-1432.

Willison, R. S. 1933. Peach canker investigations I. Some notes on incidence, contributing factors, and control measures. Sci. Agric. 14:32-47.

Yang, N., Reighard, G., Ritchie, D., Okie, W., and Gasic, K. 2013. Mapping quantitative trait loci associated with resistance to bacterial spot (Xanthomonas arboricola pv. pruni) in peach. Tree Genet. Genomes 9:573-586. 